\title{
On the Instrumentation of the Melody Line of Joseph Mysliveček's Symphonies Nos. 42-47
}

\author{
Charris Efthimiou
}

Joseph Mysliveček was the only composer of Bohemian origin who successfully established himself in Italy at around $1770 .{ }^{1}$ His operas were performed in cities such as Naples, Milan, Padova and Venice and were very positively received by both critics and the public. He was friends with W. A. Mozart and L. Mozart. J. Mysliveček's friendship with W. A. Mozart is demonstrated by his efforts at organising a contract for his friend from Salzburg to compose an opera to be played in Teatro San Carlo in Naples. ${ }^{2}$ Unfortunately, J. Mysliveček died quite young, at the age of 44, after complications from a long-term disease.

Despite his short life, he composed numerous operas as well as a series of vocal and chamber music and orchestral works. His symphonies make up only a small part of his compositional repertoire. They were composed between 1762 and 1780 and the majority of them have the standard instrumentation of strings, two horns and two oboes. Angela Evans and Robert Dearling drafted a thematic catalogue of his instrumental and orchestral works in 1999, something which is extremely important for an analysis of these works. ${ }^{3}$

1 Moritz Bauer, "Joseph Mysliveček," in Musik und Geschichte in Gegenwart (Kassel: Bärenreiter-Verlag, 2004), 264-269.

2 Simon P. Keefe, “Joseph Mysliveček,” in The Cambridge Mozart Encyclopedia, ed. Cliff Eisen and Simon P. Keefe (Cambridge: Cambridge University Press, 2006), 348-349.

3 Angela Evans and Robert Dearling, Josef Mysliveček (1737-1781). A Thematic Catalogue of His Instrumental and Orchestral Works (München and Salzburg: Musik Verlag Katzbichler, 1999). 
There are several academic articles focused on his symphonies ${ }^{4}$ and the relationship between them and those of W. A. Mozart. ${ }^{5}$ The motivic, stylistic and formal aspects of his music are discussed and analysed in these articles and compared with other works by composers of the same period. There are no monographs, however, on the symphonic works by J. Mysliveček, although a number of his symphonies have been edited. The vast majority of his orchestral works can also be found as orchestral parts in various libraries around Europe. It is noteworthy that musicology has seldom occupied itself with the instrumentational aspects of his symphonies, although W. A. Mozart's judgement on the instrumentation of his Bohemian friend was exceptionally positive. ${ }^{6}$

The aim of this paper is to examine the design of the melody line in J. Mysliveček's Symphonies nos. 42-47 (ED. 10: D21, F8, Bb8, Eb6, G10 and C11) from a music-analytical perspective. The following aspects are presented in details: instrumentation of the bass line, octave doublings of the melody line within a movement, as well as the participation of the low strings and the brass section in the performance of the melody. The playing of the melody line in octaves and doublings, the participation of the lower strings and brass instruments in the performance of the melody, the relationship between the total number of the melody constellation within a part and those which are different and the relationship between the number of melody constellations in the symphonic part and the number of bars in it are also some of the aspects which will be presented in detail.

Symphonies nos. 42-47 were composed around 1778 and have the standard instrumentation (strings, two horns and two oboes). ${ }^{7}$ The orchestral parts which are used here are found in The National Library of the Czech Republic (CZ-Pu: 59R 243, 1-6). These symphonies will consequently be compared with the following opera symphonies from the same period which also have the same instrumentation, in order to find differences and similarities between them:

- ED. 10: G6: Romolo ed Ersilia (I Nc: 29. 3. 18-20), composed 1773.

- ED. 10: Bb5: Artaserse (I Nc: 29. 4. 32-34), composed 1774.

- ED. 10: D18: Il demofoonte (I Nc: 29. 3. 7-9), composed 1775.

- ED. 10: C8: Ezio (I Nc: 29. 3. 10-12), composed 1775.

- ED. 10: C12: L'Olimpiade (I Nc: 29. 3. 15-17), composed 1778.

- ED. 10: D22: Calliroe (I Nc: 29. 3. 1-3), composed 1778.

Symphonies nos. 42-47 and the opera overtures (1773-1777) by J. Mysliveček will also be compared with W. A. Mozart's symphonies (KV162, KV 199, KV 181, KV 183, KV 201

4 Rudolf Pečman, "The Mannheim School and Josef Mysliveček," in Beiträge zur Mittelrheinischen Musikgeschichte 31, ed. Christine Heyter-Rauland and Christoph-Hellmut Mahling (Mainz: Schmidt, 1993), 75-83.

5 Wolfgang Gersthofer, Mozarts frühe Sinfonien (bis 1772): Aspekte frühklassischer Sinfonik (Salzburg: Internationale Stiftung Mozarteum, 1993).

6 Bauer, “Joseph Mysliveček,” 267.

7 Evans and Dearling, Josef Mysliveček. 
and KV 202) which were also composed during the same period and which also have the same instrumentation. I am not interested in demonstrating the suspected influences of Mozart in J. Mysliveček's music, but in analysing his works from an over-arching perspective and determining if these tendencies and templates describe a unique instrumentation style or not.

Before beginning this analysis, it is of great importance to sketch the relationship between various orchestral instruments and standard instrumentation between 1740 and 1780 (stings, two horns and two oboes). This instrumentation was crystallized at around 1740 and was the template for the conception of symphonies by many composers from different geographic areas. ${ }^{8}$

Violins and oboes were the primary carriers of the melody between 1740 and 1770 . The oboes originally doubled the strings (around 1740) but over the passage of time became increasingly independent. The bass is played by the cellos and double bases and eventually by two bassoons. ${ }^{9}$ It is apparent as of 1770 that composers are beginning to write solo parts for cellos. Wood-winds were extended by flutes and later by clarinets at around $1770 .{ }^{10}$ Up until that time, bassoons usually played along with the bass colla parte. After this point, there were always more independent bassoon parts (also in the tenor range).

Between 1740 and 1760 the brass instruments were not only composed of two horns, but there were also some symphonies with four horns and/or a number with two extra trumpets and timpani. These instruments usually played in tutti parts, where they played either long tones or had a signalling function. ${ }^{11}$

As already mentioned, the melody line of J. Mysliveček's symphonies will be compared with those of W. A. Mozart from an over-arching perspective. Only when the instrumentation and the form of the analysed works is identical and when the time window is relatively small (10-20 years), it is possible to obtain substantiated results from a comparative study. ${ }^{12}$ I will consequently only analyse the first parts of the symphonies and the first part of the opera overtures; pieces of this sort written in the mid- $18^{\text {th }}$ century actually had almost identical forms.

The tone-colours of the melody change within a symphonic movement several times. This results in a huge amount of data which describes the course of the instrumentation, which in turn makes the overview of such processes extremely difficult. It is therefore necessary to develop a system that illustrates the course of such tone-colour processes.

8 Klaus Aringer, Instrumente und musikalischer Satz im Orchester der Wiener Klassiker Haydn, Mozart und Beethoven (Tübingen: University of Tübingen, 2003), 203.

9 Aringer, Instrumente, 215.

10 Ibidem, 245-277.

11 Ibidem, 310-318.

12 Jan Beran, Interdisciplinary Statistics: Statistics in Musicology, (London: Chapman and Hall, 2004). 
The abstraction of the sound dispositions in tabular form has, on the one hand, the advantage (in terms of the large scale form) of clearly displaying the timbral processes on the one side. These kind of tables can provide information concerning the long-term trends of the instrumentation of the melody line that would otherwise remain hidden due to the large size of the symphony movement. The description of the tone-colour combinations of the melody line with symbols has, on the other hand, the advantage that one can compress all the tone-colour data of the symphonic movement into only a few lines. The review of these processes becomes much more difficult, however, as the data compression increases.

In order to achieve this specifically, there is a need to develop a system which compresses as many tone-colour constellations in a clearer way on one side with tables. As a result, long-term tendencies are visible, something which would not be possible through the various different changes of instrumentation from the beginning to the end of a movement.

Fig. 1a lists seven different instrumentations of the melody line during the first part of Symphony no. 43 (ED, 10: F8). The instruments which do not participate in the performance of the melody are not shown. The bar number of each distinct combination is also noted. Fig. 1b transfers the seven instrumentations in tabular form.

Various colours and symbols are introduced for the representation of the different places where the melody is doubled in the octaves. The colour black indicates when a melody is doubling another one (bar 18, letter B), the colour gray signifies the "octaving" (bar 39, letter D / bar 81, letter G) of a melody and the symbol "X" signifies that a melody is played two octaves higher (bar 81 , letter $\mathrm{F}$, first and second oboes).

In bars 1-2 (letter D) and 82-83 (letter E) the melody is played in thirds. For the transfer in tabular form (Fig. 1b) an extra column is inserted for reasons of clarity. The last row of the table describes the interval (third or sixth) where a melody is being played. The instruments are listed from top to bottom according to the arrangement of a modern score. The colours provide no information concerning the position, but describe the final relation that the two melodies have. 
Fig. 1a:

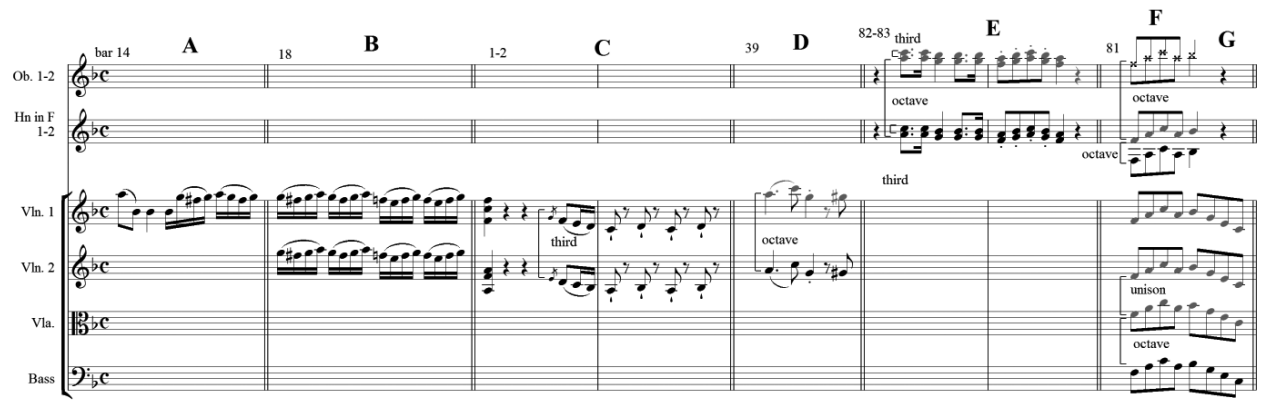

Fig. 1b:

\begin{tabular}{|l|c|c|c|c|c|c|c|}
\hline situation & A & B & C & D & E & F & G \\
\hline Bar & 14 & 18 & $1-2$ & 39 & $82-83$ & 81 & 81 \\
\hline ob. 1 & & & & & & X & \\
ob. 1 & & & & & $\square$ & X & \\
\hline $\begin{array}{l}\text { hn. 1 } \\
\text { hn. 2 }\end{array}$ & & & & & & $\square$ & \\
\hline $\begin{array}{l}\text { vln. 1 } \\
\text { vln. 2 } \\
\text { vla. } \\
\text { bass }\end{array}$ & $\square$ & $\square$ & $\square$ & $\square$ & & $\square$ & $\square$ \\
\hline Interval & & & & $\square$ & & $\square$ & $\square$ \\
\hline
\end{tabular}

Fig. 2 attempts to consider the melody line of the first part of Symphony no. 44 (ED, 10: $\mathrm{Bb} 8$ ) from an over-arching perspective and lists all the instrumentation changes of the melody line in tabular form.

Fig. 2 provides the following results:

- All the instruments play the melody.

- During the first movement, the tone-colour of the melody changes 49 times. 14 of them are different, that is, $28,5 \%$ of them.

- The first part of Symphony no. 43 is 88 bars long and the tone-colour of the melody changes 49 times. This change is consequently quite high.

- There are combinations with only one (10), two (6), four (18) and five or more (15) instruments. 33 of the 49 combinations include four or more instruments. The melody line of this part is rich and full of tone-colours. 
- 16 combinations are in unison, 18 are within one octave and 14 within two. This symphony movement is characterized not only by the constant tone-colour change, but also by the constant change in the density of the melody line.

- There are 22 combinations in thirds and sixths (including doublings). Of these 22, only 4 are in sixths. J. Mysliveček preference for the melody in thirds instead of in sixths is apparent.

- The first violins play the melody alone five times, the second violins five times and both together six times. The tone-colour of the violins is not dominant here, the opposite being true for symphonies during the 1750 s and 1760 s. In contrast to composers of the mid- $18^{\text {th }}$ century, ${ }^{13}$ composers at the end of the $18^{\text {th }}$ century reduced the dominance of violins due to the instrumentation of the melody line with the standard instrumentation.

- The violas and double bases participate 15 times in the performance of the melody and the horns 7 times. This is another instrumentation characteristic which is typical for symphonies of the 1770s and not for orchestral works of the 1750s and 1760s. ${ }^{14}$

Fig. 2: J. Mysliveček, Symphony no. 44 (ED. 10: Bb8): complete tone-colour constellations of the melody line

\begin{tabular}{|c|c|c|c|c|c|c|c|c|c|c|c|c|c|c|c|}
\hline Bar & 1 & $1 / 2$ & 1 & 3 & $4 / 6$ & $5 / 7$ & 6 & 7 & 8 & 11 & 13 & 16 & 19 & 21 & 23 \\
\hline $\begin{array}{l}\text { ob. } 1 \\
\text { ob. } 1\end{array}$ & 口 & $\begin{array}{l}X \\
X\end{array}$ & $\begin{array}{l}\mathrm{X} \\
\mathrm{X}\end{array}$ & & $\begin{array}{l}X \\
X\end{array}$ & 口 & $\mathbf{\square}$ & 口 & 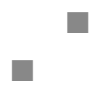 & & $\begin{array}{l}X \\
X\end{array}$ & $\mathbf{\square}$ & & $\begin{array}{l}X \\
X\end{array}$ & \\
\hline $\begin{array}{l}\text { hn. } 1 \\
\text { hn. } 2 \\
\end{array}$ & & $\square$ & & & & & & & 口 & & & & & & \\
\hline $\begin{array}{l}\text { vln. } 1 \\
\text { vln. } 2 \\
\text { vla. } \\
\text { Bass } \\
\end{array}$ & $\begin{array}{l}\mathbf{a} \\
\mathbf{\square}\end{array}$ & $\begin{array}{l}\mathbf{X} \\
\mathbf{X} \\
\mathbf{\square} \\
\end{array}$ & $\begin{array}{l}X \\
X \\
\square \\
\end{array}$ & 口 & \begin{tabular}{|c|}
$\mathbf{X}$ \\
$\mathbf{X}$ \\
$\mathbf{\square}$ \\
\end{tabular} & $\mathbf{\square}$ & $\begin{array}{l}\mathbf{a} \\
\mathbf{\square}\end{array}$ & 口 & 口 & 口 & $\begin{array}{l}X \\
X \\
\square \\
\end{array}$ & $\mathbf{\square}$ & 口 & $\begin{array}{l}\square \\
\square \\
\square \\
\square \\
\end{array}$ & $\mathbf{\square}$ \\
\hline Interv & & & & & & third & & third & third & third & & third & third & & \\
\hline
\end{tabular}

13 Charris Efthimiou, Strategien orchestraler Gestaltung in Mozarts frühe Sinfonien: Eine Musikanalytische Studie (Saarbrücken: Südwestdeutscher Verlag für Hochschulschriften, 2014).

14 Charris Efthimiou, "Strategien Orchestraler Gestaltung in W. A. Mozart's frühe Sinfonien," in Mozart Jahrbuch 2016, ed. Manfred Hermann Schmidt (Salzburg: Internationale Stiftung Mozarteum, 2016) [to be edited]. 


\begin{tabular}{|c|c|c|c|c|c|c|c|c|c|c|c|c|}
\hline Bar & 29 & 30 & 32 & $35 / 3$ & $736 / 38$ & 39 & 42 & 43 & $44 / 46$ & 43 & 48 & 52 \\
\hline $\begin{array}{l}\text { ob. } 1 \\
\text { ob. } 1\end{array}$ & $\square$ & & & & $\mathbf{\square}$ & $\begin{array}{l}X \\
X\end{array}$ & & $\begin{array}{l}\mathrm{X} \\
\mathrm{X}\end{array}$ & 口 & 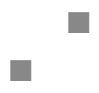 & & \\
\hline $\begin{array}{l}\text { hn. } 1 \\
\text { hn. } 2\end{array}$ & & & & & & & & & & 口 & & \\
\hline $\begin{array}{l}\text { vln. } 1 \\
\text { vln. } 2 \\
\text { vla. } \\
\text { bass }\end{array}$ & 口 & 口 & $\square$ & ש & 口 & $\begin{array}{l}X \\
X \\
\square\end{array}$ & $\square$ & $\begin{array}{l}\mathbf{X} \\
\mathbf{X} \\
\mathbf{\square}\end{array}$ & a & 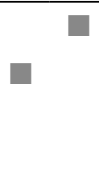 & a & $\begin{array}{l}X \\
X \\
\square\end{array}$ \\
\hline Interv & third & Third & & & sixth & & & & third & third & third & \\
\hline
\end{tabular}

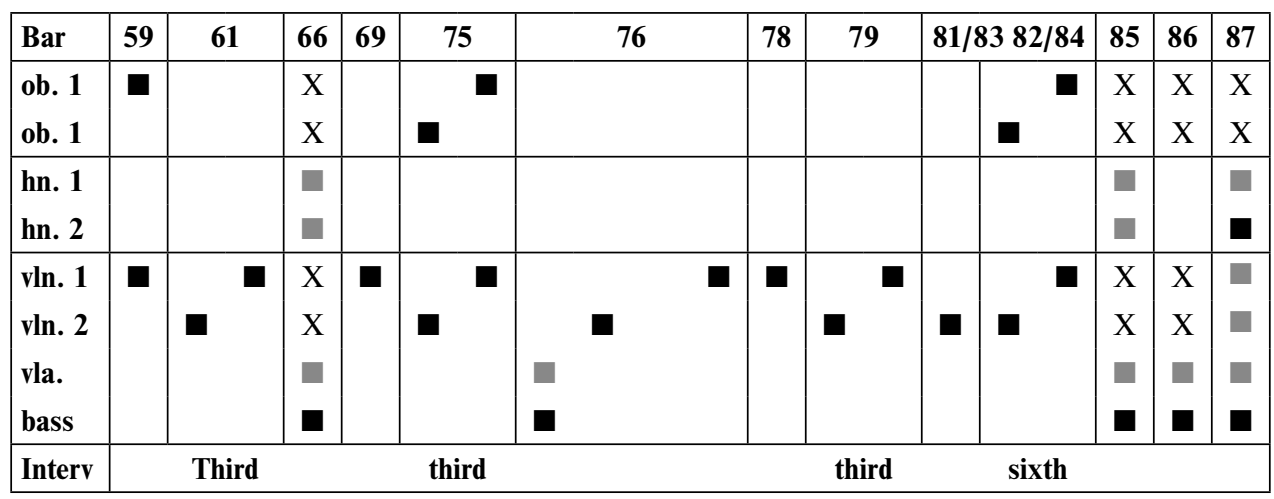

After considering the above points, it is apparent that the first part of Symphony no. 44 (ED, 10: $\mathrm{Bb} 8$ ) is very diverse with respect to the instrumentation of the melody line. Although Mysliveček has a limited amount of instruments at his disposal, he tries to get the maximum out of them. There are constellations with different densities and tonecolours, in unison, in thirds and sixths, as well as with the participation of instruments (horns and double basses) which according to the standards of the time, were not responsible for playing the melody. ${ }^{15}$

\footnotetext{
Aringer, Instrumente, 215.
} 
Fig. 3: Listing of all melody constellations of the first part of Symphony no. 45 (ED. 10: Eb6) by J. Mysliveček until bar 22
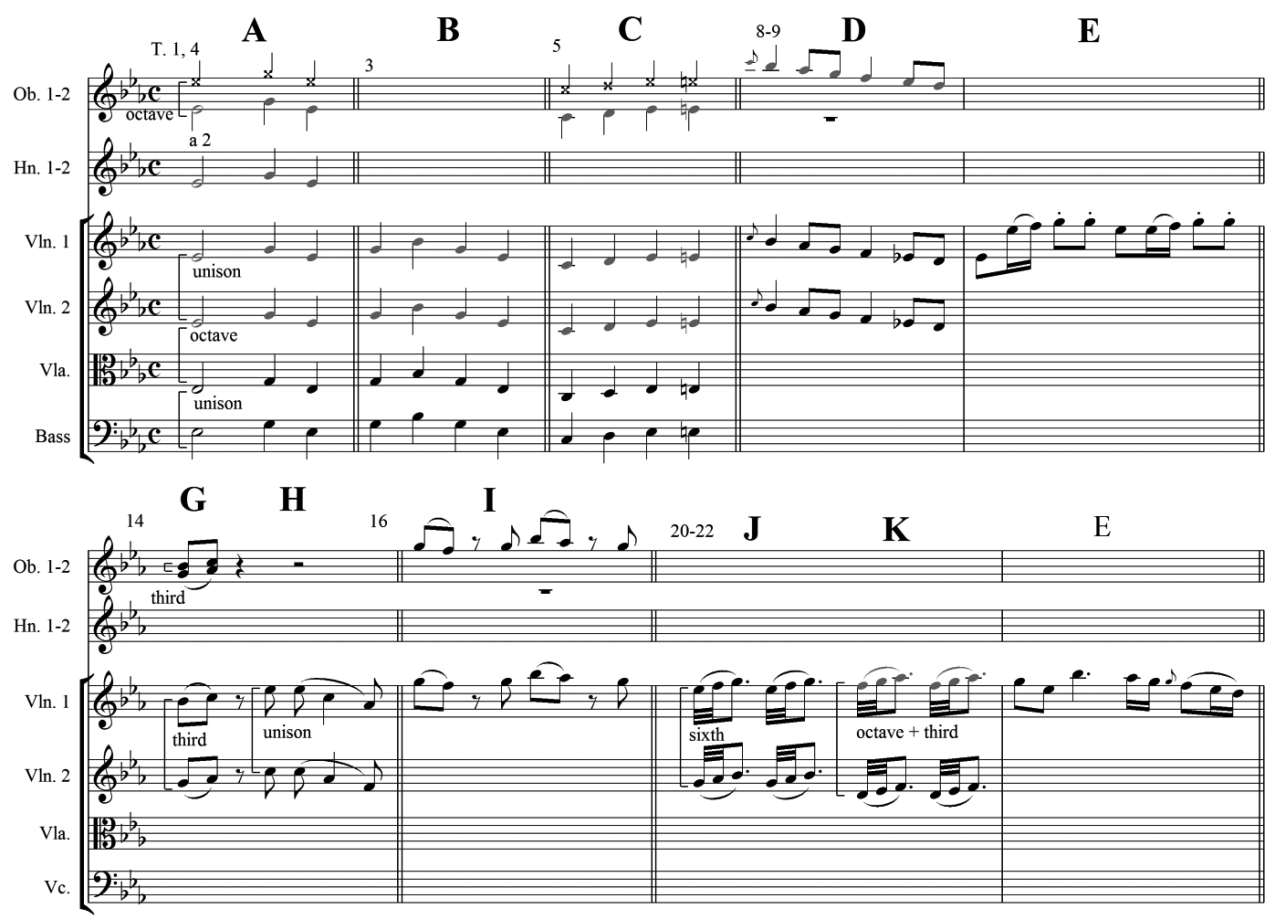

Fig. 3 demonstrates the development of the entire melody line in the first 22 bars of the first part of Symphony no. 45 (ED, 10: Eb6). The instrumentation of the melody line changes during the first movement of this symphony quite often, and due to space limitations, I only show the first bar of each different instrumentation. In order to improve the clarity of Fig. 3, a double line is inserted between every instrumentation. The instruments which do not participate in the performance of the melody are not shown. I also note the number of bars of each different constellation. A letter has been inserted above each constellation. The first constellation has the letter A (bold with italics), the second the letter B (again bold with italics), etc. When the constellation E (bar 22: first violins) is repeated, this is noted above the bar with the letter E again (for example in bar 22) but without bold and italics. 
During the first 22 bars of this movement there are melodies:

- In unison (letters $\mathrm{H}$ and $\mathrm{I}$ ), thirds $(\mathrm{G})$, sixths $(\mathrm{J})$, one octave (B and D), tenths (K), two octaves (A and C)

- With one (E), two (H, I, J, K), three (D), four (B and G) and more than five (A and C) instruments.

- With horns (A), lower (violas and double basses) strings (A, B and C) and oboes (A, C, D and I)

- Only with the first violins (E) and with both the first and second violins (H, J, K)

The richness of tone-colours in these first 22 bars is enormous. Up until bar 21, there are actually no tone-colour repetitions. This indicates that J. Mysliveček was in a position to develop and realize mid to long-term tendencies in instrumentation. Such processes are to be found in the first movements of all the sixth symphonies (Nos. 42-47). Symphony no. 45 was chosen here as exemplary.

If one examines Fig. 2 (Symphony no. 44) from an over-arching perspective, it is apparent that in this part of Symphony no. 44 (ED, 10: Eb6) there are numerous orchestratutti (bars 1, 2, 4, 13, 21, 39, 43, 52, 66, 85, 86 and 87). Fig. 4 attempts to present the orchestra-tutti in tabular form. Each combination is noted with the letter seen in the bottom of the tabular.

Fig. 4: Listing of all orchestra-tutti of the first part of Symphony no. 44 (ED, 10: Eb6) by J. Mysliveček

\begin{tabular}{|c|c|c|c|c|c|c|c|c|c|c|c|c|}
\hline bar & 1 & 2 & 4 & 13 & 21 & 39 & 43 & 52 & 66 & 85 & 86 & 87 \\
\hline ob. 1 & $X$ & $X$ & $X$ & $X$ & $X$ & $X$ & $X$ & $X$ & $X$ & $\mathrm{X}$ & $X$ & $X$ \\
\hline ob. 1 & $X$ & $X$ & $X$ & $\mathrm{X}$ & $X$ & $X$ & $X$ & $X$ & $X$ & $X$ & $X$ & $X$ \\
\hline $\begin{array}{l}\text { hn. } 1 \\
\text { hn. } 2\end{array}$ & घ & & & & & & & & 口 & घ & & च \\
\hline vln. 1 & $X$ & $X$ & $X$ & $X$ & $\square$ & $X$ & $X$ & $X$ & $X$ & $\mathrm{X}$ & $X$ & 口 \\
\hline vln. 2 & $X$ & $X$ & $\mathrm{X}$ & $X$ & घ & $X$ & $X$ & $X$ & $X$ & $X$ & $X$ & $\square$ \\
\hline vla. & $\square$ & $\square$ & 口 & 口 & च & 口 & $\square$ & 口 & $\square$ & $\square$ & 口 & $\square$ \\
\hline bass & $\square$ & $\mathbf{\square}$ & $\mathbf{\square}$ & $\square$ & 口 & 口 & 口 & 口 & $\mathbf{\square}$ & $\mathbf{0}$ & $\mathbf{\square}$ & $\mathbf{\square}$ \\
\hline comb. & $\mathbf{A}$ & B & B & B & C & B & B & B & $\mathbf{A}$ & $\mathbf{A}$ & B & D \\
\hline
\end{tabular}

Although during Symphony no. 44 there is a high degree of tone-colour differentiation, J. Mysliveček often repeats the tone-colours of certain orchestra-tutti of the symphony (Fig. 4 combinations A and B). These orchestra-tutti differ strongly in harmony and motif but not in tone-colours. The transfer of all the tone-colour constellation in tabular form has an abstract character which, at first glance, drives us quickly to such concrete results. 
All the orchestra-tutti from other symphonies by J. Mysliveček (No. 43: ED, 10: D21 and No. 43: ED, 10: F8) are finally presented in the same way as before in order to compare them with Symphony no. 44 (Fig. 5).

Fig. 5: Listing of all orchestra-tutti of the first parts of Symphony no. 43: ED, 10: D21 and Symphony no. 43: ED, 10: F8 by J. Mysliveček

\begin{tabular}{|l|c|c|c|c|c|c|c|c|c|c|c|c|c|c|c|c|}
\hline & \multicolumn{10}{|c|}{ Symphony no. 42 } & \multicolumn{1}{|c|}{ Symphony no. 43} \\
\hline Bar & $\mathbf{3 1}$ & $\mathbf{6 6}$ & $\mathbf{7 6}$ & $\mathbf{7 8}$ & $\mathbf{8 6}$ & $\mathbf{8 7}$ & $\mathbf{1 0 5} 118$ & $\mathbf{2 8}$ & $\mathbf{3 1}$ & $\mathbf{4 3}$ & $\mathbf{4 8}$ & $\mathbf{8 0}$ & $\mathbf{9 5}$ & $\mathbf{9 9}$ \\
\hline Bar & $\mathrm{X}$ & $\mathrm{X}$ & $\mathrm{X}$ & $\mathrm{X}$ & & $\mathrm{X}$ & $\mathrm{X}$ & $\mathrm{X}$ & $\mathrm{X}$ & & $\mathrm{X}$ & & $\mathrm{X}$ & $\mathrm{X}$ & $\square$ \\
ob. 1 & $\mathrm{X}$ & $\mathrm{X}$ & $\mathrm{X}$ & $\mathrm{X}$ & & $\mathrm{X}$ & $\mathrm{X}$ & $\mathrm{X}$ & $\mathrm{X}$ & & $\mathrm{X}$ & & $\mathrm{X}$ & $\mathrm{X}$ & $\square$ \\
\hline ob. 1 & & & & $\square$ & $\square$ & $\square$ & & $\square$ & & & & & $\square$ & & $\square$ \\
hn. 1 & & & & $\square$ & $\square$ & $\square$ & & $\square$ & & & & & $\square$ & & $\square$ \\
\hline hn. 2 & $\square$ & $\mathrm{X}$ & $\square$ & $\square$ & $\square$ & $\square$ & $\mathrm{X}$ & $\mathrm{X}$ & $\square$ & $\square$ & $\mathrm{X}$ & $\square$ & $\square$ & $\mathrm{X}$ & $\square$ \\
vln. 1 & $\square$ & $\mathrm{X}$ & $\square$ & $\square$ & $\square$ & $\square$ & $\mathrm{X}$ & $\mathrm{X}$ & $\square$ & $\square$ & $\mathrm{X}$ & $\square$ & $\square$ & $\mathrm{X}$ & $\square$ \\
vln. 2 & $\square$ & $\square$ & $\square$ & $\square$ & $\square$ & $\square$ & $\square$ & $\square$ & $\square$ & $\square$ & $\square$ & $\square$ & $\square$ & $\square$ & $\square$ \\
vla. & $\square$ & $\square$ & $\square$ & $\square$ & $\square$ & $\square$ & $\square$ & $\square$ & $\square$ & $\square$ & $\square$ & $\square$ & $\square$ & $\square$ & $\square$ \\
\hline
\end{tabular}

It is apparent that, in terms of the instrumentation of the orchestra-tutti, Symphony no. 42 (fig. 5) is diametrically different from Symphony no. 44 (Fig. 4). Every orchestra-tutti of Symphony no. 42 has a different tone-colour. Almost the same is true for Symphony no. 43.

Although J. Mysliveček has a limited number of instruments at his disposal, he tries to achieve the maximum out of his possibilities. After an analysis of the tone-colours in the first movements of his Symphonies nos. 42-47, it is apparent that he composes his melodies with different densities and tone-colours, as well as in different intervals. A high degree of tone-colour differentiation provides no information on the quality of the composition whatsoever. As mentioned in the introduction, I wish to analyse the differences and similarities between Symphonies nos. 42-47 and his operas and the works of other composers.

The different strategies which J. Mysliveček uses for the instrumentation of his orchestra-tutti, makes it essential to not only analyse these symphonies with one other, but also to compare them with opera overtures by the composer and with the works of others in order to have substantiated results. 
Fig. 6: Opera overture by J. Mysliveček Calliroe (ED. 10: D22), complete tone-colour constellations of the melody line

\begin{tabular}{|c|c|c|c|c|c|c|c|c|c|c|c|c|c|c|c|}
\hline bar & 1 & 3 & 9 & 16 & \multicolumn{2}{|c|}{$1820 / 22$} & 23 & 25 & 35 & 37 & 40 & 43 & 44 & 45 & 46 \\
\hline ob. 1 & $\mathrm{X}$ & $\mathrm{X}$ & & $\mathbf{\square}$ & & $\square$ & $\mathrm{X}$ & & & & $\mathbf{\square}$ & & 口 & च & $\mathrm{X}$ \\
\hline ob. 1 & $\mathrm{X}$ & $X$ & & & & & $\mathrm{X}$ & & & & & & & & $\mathrm{X}$ \\
\hline hn. 1 & $\square$ & & & & & $\mathbf{0}$ & & & & & & & & & $\square$ \\
\hline hn. 2 & $\mathbf{\square}$ & & & & & & & & & & & & & & $\mathbf{\square}$ \\
\hline vln. 1 & $\square$ & $\square$ & $\mathbf{\square}$ & $\mathbf{\square}$ & $\mathbf{\square}$ & $\square$ & $\mathrm{X}$ & $\square$ & $\square$ & $\mathbf{\square}$ & $\mathbf{0}$ & $\square$ & 口 & $\mathbf{\square}$ & $\mathrm{X}$ \\
\hline vln. 2 & 口 & $\square$ & & & & & $\mathrm{X}$ & - & $\mathbf{\square}$ & & & $\mathbf{\square}$ & & & $X$ \\
\hline vla. & 口 & 口 & & & & & $\square$ & & & & & & & & 口 \\
\hline bass & $\mathbf{\square}$ & $\mathbf{\square}$ & & & & & 口 & - & & & & & & & $\mathbf{\square}$ \\
\hline Interv & & & & & & & & third & & & & third & third & sixth & \\
\hline
\end{tabular}

\begin{tabular}{|c|c|c|c|c|c|c|c|}
\hline bar & 48 & 50 & 51 & 52 & 53 & 54 & 62 \\
\hline $\begin{array}{l}\text { ob. } 1 \\
\text { ob. } 1 \\
\end{array}$ & & 口 & & 口 & a & & 口 \\
\hline $\begin{array}{l}\mathrm{hn} .1 \\
\mathrm{hn} .2\end{array}$ & & & & & & & \\
\hline $\begin{array}{l}\text { vln. } 1 \\
\text { vln. } 2 \\
\text { vla. } \\
\text { bass }\end{array}$ & 口 & 口 & 口 & a & a & 口 & \\
\hline Interv & sixth & sixth & third & third & third & & Third \\
\hline
\end{tabular}

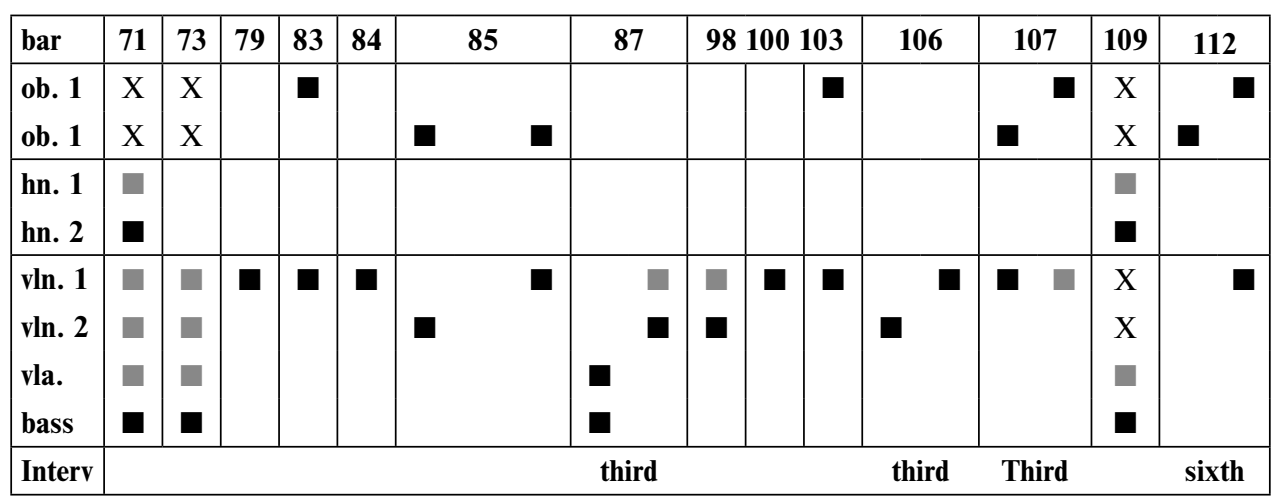


Fig. 2 to 5 describe the tone-colour characteristics of Symphonies nos. 42-47. Fig. 6 to 8 attempt to analyse using the same criteria his opera symphonies (1773-1778). In numerous aspects, these six overtures from the 1770s have many similarities with Symphonies nos. 42-47. Fig. 6 lists all instrumentations of the melody line of the opera overture Calliroe (I Nc: 29. 3. 1-3) by J. Mysliveček in tabular form.

Fig. 6 provides the following results:

- All instruments participate in the performance of the melody.

- During the first movement, the tone-colour of the melody line changes 37 times. 22 of these are different, i.e. $59,4 \%$ of them.

- There are combinations with only one (6), two (9), three (3), four (8) and with five or more instruments (11). The overture is very well-balanced with respect to the density of the melody line.

- 14 combinations are in unison, 16 in one and 7 in two octaves.

- There are 14 constellations in thirds and sixths (including doubling). 10 of them are solely in sixths.

- The first violins play the melody alone six times, 5 times together with the seconds, while the seconds never play the melody alone.

- The lower strings participate in the performance of the melody nine times, while the horns participate five times.

If we now compare the opera overture of Calliroe (1778) with the first movement of Symphony no. 44 (1778), it is apparent that there are more differences than similarities (with respect to the tone-colour design of the melody line).

- The overture is much longer that the first movement of Symphony no. 44.

- At the same time, however, the tone-colour of the melody changes more often in Symphony no. 44 (44 times in 88 bars) than in Calliroe ( 37 times in 113 bars).

- The tone-colour differentiation in Calliroe is much higher than that of Symphony no. 44 (59,4\% of all constellations in Calliroe are different while in Symphony no. 44 the number is $25,5 \%$ ).

- Most of the melodies in Symphony no. 44 are composed for more than two instruments; in Calliroe there is more balance in that respect.

There are also similarities, however, between the two works:

- Melodies in unison, in one or two octaves, are more dominant than melodies in thirds, sixths or tenths. Melodies in thirds and tenths are more often than ones in sixths.

- Instruments which were seldom used to perform melodies during the 1750 s and 1760 s are used quite often here (horns, violas and double basses)

The comparison of these two works demonstrates that, although they were composed within one or two years of one other, they differ in many respects. It is, therefore, problematic 
to talk about an instrumentation style of a small time period (in this case the style of symphonic works of the 1770s in Central Europe), as well as about a specific instrumentation style of a composer. Despite the differences between the two works, Fig. 7 and 8 indicate that there are indeed also similarities between the concert symphonies and the opera overtures by J. Mysliveček. In the first 30 to 50 bars of Symphonies nos. 42-47, melodies with various tone-colours are heard. Only after cca the second third of the first movement does one hear tone-colour constellations being repeated. This holds for all six opera overtures as well.

Fig. 7: Listing of all melody constellations of the opera overture Ezio by J. Mysliveček (ED, 10: C8), bars two to six

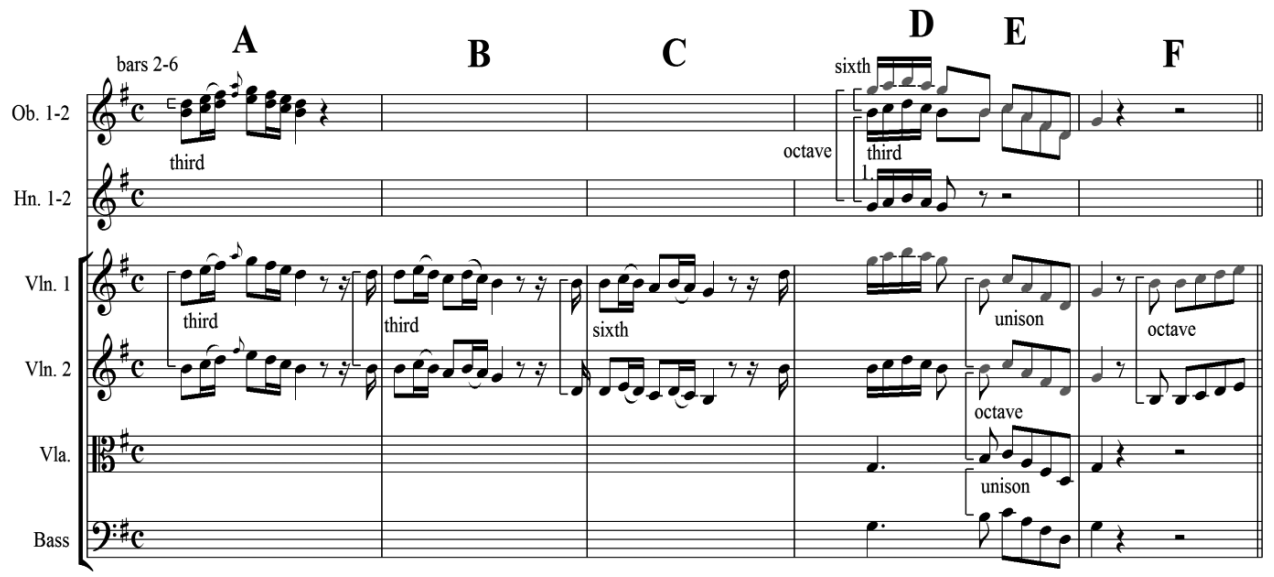

I present here (Fig. 7) bars two to six of the overture of the opera Ezio (ED, 10: C8) exemplary. Within only six bars one hears melodies with different tone-colours (e.g. only violins: letter B, C, and F, violins with oboes: letter A) and density (two instruments: $\mathrm{B}$, C, F, four instruments: A, five instruments: D, six instruments: E) as we all in unison or two octaves.

Fig. 6 (Ezio) as well as Fig. 3 (Symphony no. 45) describe the distinctive strategy that J. Mysliveček uses in order to organise the entire sound of the symphonic over the longterm. At the beginning we hear many and different constellations. Until the first third of the part, J. Mysliveček avoids tone-colour repetitions. After the second third, however, he turns the entire thing over: older constellations are repeated often and only at the end of the part does he use new ones. 
Fig. 8: Listing of all orchestra-tutti of the opera overtures Calliroe (ED. 10: D22) and L'Olympiade (ED. 10: C12) by J. Mysliveček

\begin{tabular}{|c|c|c|c|c|c|c|c|c|c|c|c|c|c|c|c|c|c|c|}
\hline \multirow{3}{*}{\begin{tabular}{|l|} 
bar \\
ob. 1
\end{tabular}} & \multicolumn{7}{|c|}{ Calliroe (1778) } & \multicolumn{11}{|c|}{ Olympiade (1778) } \\
\hline & \multirow{2}{*}{$\begin{array}{c}\mathbf{1} \\
\mathrm{X}\end{array}$} & \multirow{2}{*}{\begin{tabular}{|l|}
3 \\
$X$
\end{tabular}} & \multirow{2}{*}{\begin{tabular}{|l|}
23 \\
$X$
\end{tabular}} & \multirow{2}{*}{\begin{tabular}{|l}
46 \\
$X$
\end{tabular}} & \multirow{2}{*}{$\begin{array}{l}71 \\
X\end{array}$} & \multicolumn{2}{|c|}{73109} & \multirow{2}{*}{$\begin{array}{l}1 \\
X\end{array}$} & \multirow{2}{*}{$\begin{array}{l}\mathbf{5} \\
X\end{array}$} & \multirow{2}{*}{\begin{tabular}{|l|}
8 \\
$X$
\end{tabular}} & \multirow{2}{*}{\begin{tabular}{|l|}
9 \\
$X$
\end{tabular}} & \multirow{2}{*}{\begin{tabular}{|l|}
45 \\
$X$
\end{tabular}} & \multirow[t]{2}{*}{58} & \multirow{2}{*}{$\frac{73}{X}$} & \multirow{2}{*}{$\begin{array}{l}77 \\
X\end{array}$} & \multirow[t]{2}{*}{85} & \multicolumn{2}{|c|}{104117} \\
\hline & & & & & & $\mathrm{X}$ & $\mathrm{X}$ & & & & & & & & & & $\mathrm{X}$ & \\
\hline ob. 1 & $\mathrm{X}$ & $\mathrm{X}$ & $\mathrm{X}$ & $\mathrm{X}$ & $\mathrm{X}$ & $\mathrm{X}$ & $\mathrm{X}$ & $\mathrm{X}$ & $\mathrm{X}$ & $\mathrm{X}$ & $\mathrm{X}$ & $\mathrm{X}$ & & $\mathrm{X}$ & $\mathrm{X}$ & & $\mathrm{X}$ & \\
\hline $\begin{array}{l}\text { hn. } 1 \\
\text { hn. } 2\end{array}$ & 口 & & & $\square$ & $\square$ & & 口 & $\square$ & & 口 & & & & $\square$ & & & $\square$ & \\
\hline vln. 1 & $\square$ & $\square$ & $X$ & $X$ & $\square$ & $\square$ & $X$ & $\square$ & $\square$ & $\square$ & $\square$ & $\square$ & $\square$ & 口 & $\square$ & 口 & $\square$ & $\square$ \\
\hline vln. 2 & $\square$ & $\square$ & $\mathrm{X}$ & $\mathrm{X}$ & $\mathbf{\square}$ & $\mathbf{\square}$ & $\mathrm{X}$ & $\mathbf{\square}$ & $\boldsymbol{\square}$ & $\square$ & च & $\mathbf{\square}$ & 口 & 口 & $\mathbf{\square}$ & 口 & $\boldsymbol{\square}$ & 口 \\
\hline vla. & $\mathbf{\square}$ & $\mathbf{\square}$ & $\mathbf{\square}$ & $\mathbf{\square}$ & $\mathbf{\square}$ & $\mathbf{\square}$ & $\square$ & $\mathbf{\square}$ & $\mathbf{\square}$ & 口 & 口 & $\mathbf{\square}$ & $\mathbf{\square}$ & 口 & $\mathbf{\square}$ & 口 & $\square$ & 口 \\
\hline bass & $\mathbf{\square}$ & $\mathbf{\square}$ & $\mathbf{\square}$ & $\mathbf{\square}$ & $\mathbf{\square}$ & $\mathbf{\square}$ & $\mathbf{\square}$ & $\mathbf{\square}$ & a & a & 口 & 口 & a & 口 & 口 & 口 & 口 & \\
\hline
\end{tabular}

Fig. 8 confirms this argument, which is particularly problematic as one cannot actually speak of a specific personal instrumentation style for the design of the melody line in the 1770s. Although during some orchestra-tutti in Symphony no. 44 (Fig. 4) and Symphony no. 42 (Fig. 5) are repeated often, J. Mysliveček avoids tone-colour repetitions in orchestratutti of Symphony no. 43 almost entirely. The two different strategies are confirmed in Fig. 8. Most orchestra-tutti of Olympiade are based on three constellations (bars 1, 8, 104 and 107) while in Calliroe one sees less tone-colour constellations (bar 3 correlates with bar 74 and bar 46 with bar 109) which are repeated.

The method of tabular presentation of tone-colours was used up until now in this paper in order to compare concert symphonies with opera overtures composed by J. Mysliveček. The evaluation of this statistical method has led us to quick and concrete results. There are, however, a number of symphonies which do not emerge from this template. This is the reason why it would be necessary to compare symphonies by J. Mysliveček with symphonies of W. A. Mozart (KV162, KV 199, KV 181, KV 183, KV 201 and KV 202) from the same period (1773-1774) and with the same instrumentation.

W. A. Mozart is one of the most active composers of his time in the area of symphonic works. He composed more than 60 of them and made a substantial contribution to the genre. The vast majority of scholarly music publications on the analysis of Mozart's symphonies are focused on music analysis and analysis of harmony. Aspects of orchestration or detailed instrumentation analysis have rarely been considered. ${ }^{16}$

16 Except: Ellwood Derr, "Basso Continuo in Mozart's Piano Concertos: Dimensions of Compositional Completion and Performance Practice," in Mozart's Piano Concertos: Text, Context, Interpretation, ed. Neal Zaslaw (Michigan: University of Michigan Press, 1996), 393-410 and: Cliff Eisen, "The Scoring of the Orchestral Bass Part," in Mozart's Salzburg Keyboard Concertos: The Evidence of the Authentic Copies, ed. Neal Zaslaw (Michigan: University of Michigan Press, 1996), 411-425. 
The deficits in research of W. A. Mozart's orchestral dispositions are summarized:

- There is almost no literature on the design of bass and melody lines, ${ }^{17}$ although the creation of a framework set (that is, the conception of melody and bass lines) in the aetiology of Wolfgang Amadeus Mozart's compositions is of exceptional importance.

- The same is true for the orchestration of the bass and melody lines.

- The instrumentation analyses of Mozart's symphonies usually consider a small section of a symphonic part. There is therefore a lack of articles which consider the orchestration strategies of an entire symphony or of an entire symphony part.

The examination of symphonies KV 162, KV 199, KV 181, KV 183, KV 201 and KV 202, with the same analytical methods used in J. Mysliveček's symphonies, would then be an addition to Mozart research in the area of instrumentation.

Fig. 9: Listing of all melody constellations of bars 1 to 42 of the fifth part of Symphony KV 199 by W. A. Mozart
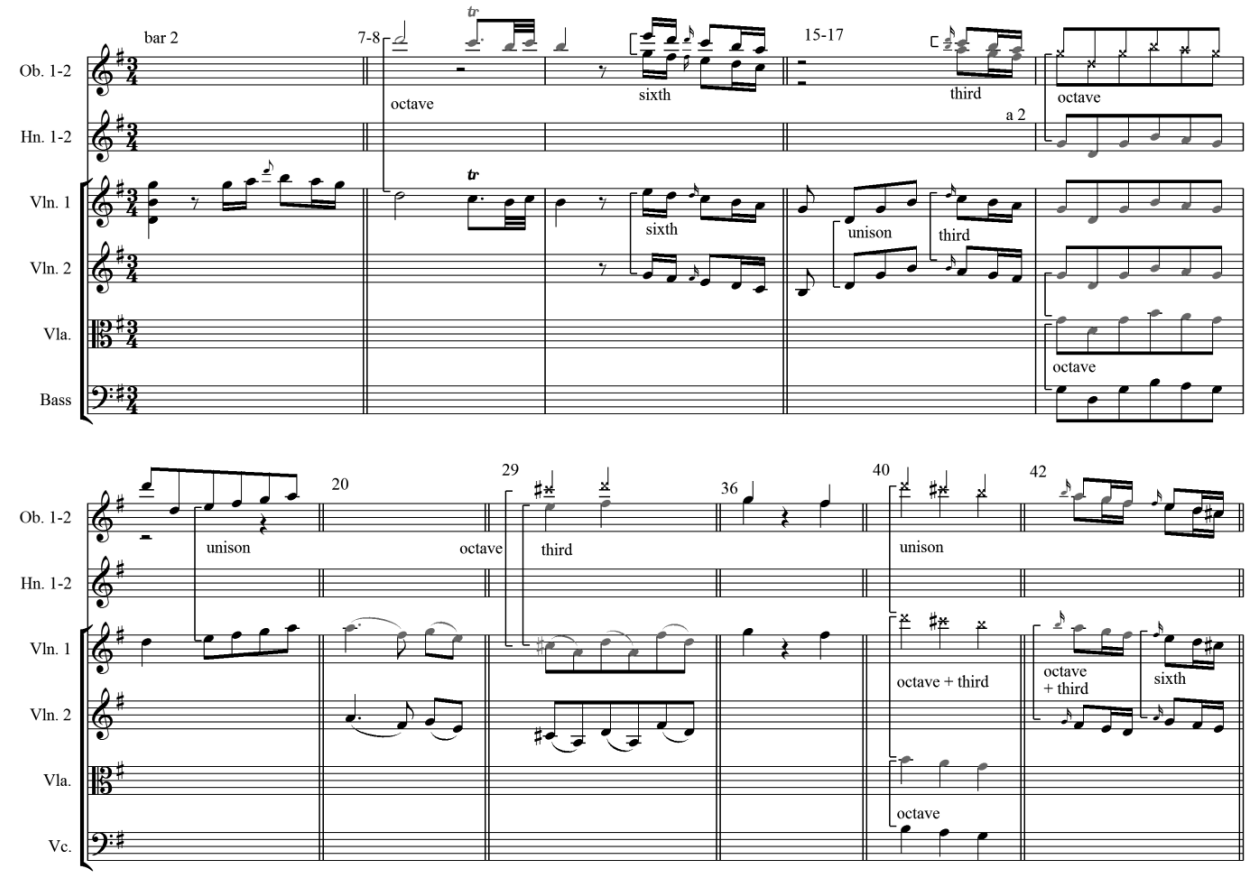

17 Except: Neal Zaslaw and John Spitzer, The Birth of the Orchestra (Oxford: Oxford University Press, 2004) and: Christoph Reuters, "Klangfarbe und Instrumentation: Geschichte-Ursachen-Wirkung," in Systematische Musikwissenschaft, ed. Jobst P. Fricke (Frankfurt am Main: Peter Lang, 2002). 
Fig. 9 indicates that Mozart instruments the first part of his Symphony KV 199 from bar 1 to 42 in a similar manner as J. Mysliveček. In only 42 bars, the instrumentation of the melody line changes 13 times and there is no tone-colour constellation which is repeated. Only after bar 43, like in J. Mysliveček, do we hear repetitions of constellations. In those 42 bars there are melodies in unison (bar 15 and 36), thirds (15, 29 and 42), sixths ( 8 and 42$)$, in one octave $(7,15,19,20,36)$, in tenths (42), in two octaves (16 and 40), with one (2), two $(7,15,19,20,36)$, four $(8,15,29$ and 42$)$, five (4) and more than six instruments (16). Both composers follow the same ideals.

Fig. 10: Listing of all orchestra-tutti of the first parts of the Symphonies KV 199, 62, 201 and 202 by W. A. Mozart

\begin{tabular}{|c|c|c|c|c|c|c|c|c|c|c|c|c|c|c|c|c|c|c|c|}
\hline \multirow{3}{*}{\begin{tabular}{|l|} 
bar \\
Ob. 1 \\
\end{tabular}} & \multirow{2}{*}{\multicolumn{3}{|c|}{$\begin{array}{c}\text { KV } 199 \\
16102143 \\
\end{array}$}} & \multicolumn{4}{|c|}{ KV 162} & \multicolumn{4}{|c|}{ KV 201} & \multicolumn{8}{|c|}{ KV 202} \\
\hline & & & & \multirow{2}{*}{18} & \multirow{2}{*}{$\frac{22}{X}$} & \multirow{2}{*}{85} & \multirow{2}{*}{$\begin{array}{c}89 \\
X\end{array}$} & \multirow{2}{*}{\begin{tabular}{l|}
77 \\
$X$
\end{tabular}} & \multirow{2}{*}{89} & \multicolumn{2}{|c|}{181201} & \multirow{2}{*}{8} & \multirow{2}{*}{28} & \multicolumn{3}{|c|}{71102120} & \multicolumn{3}{|c|}{141190204} \\
\hline & $\mathbf{X}$ & $\mathbf{X}$ & $\mathbf{X}$ & & & & & & & & & & & $\mathbf{X}$ & $\square$ & 口 & $\mathbf{X}$ & $\square$ & $\mathbf{X}$ \\
\hline Ob. 2 & $\mathbf{X}$ & $\mathbf{X}$ & $\mathbf{X}$ & $\square$ & $\mathbf{X}$ & 口 & $\mathbf{X}$ & $\mathbf{X}$ & $\square$ & & & 口 & 口 & $\mathbf{X}$ & $\square$ & 口 & $\mathbf{X}$ & 口 & $\mathbf{X}$ \\
\hline Hn. 1 & 口 & 口 & 口 & & 口 & & 口 & & & & & & & & & & & & 口 \\
\hline Hn.2 & 口 & $\square$ & $\square$ & & & & & & & & & & & & & & & & $\square$ \\
\hline Vln. 1 & $\square$ & 口 & $\square$ & $\square$ & $\square$ & $\square$ & $\square$ & $\square$ & $\square$ & $\square$ & 口 & $\square$ & $\square$ & $\square$ & $\square$ & $\square$ & $\square$ & $\square$ & $\mathbf{X}$ \\
\hline Vln. 2 & $\square$ & 口 & $\square$ & $\mathbf{\square}$ & 口 & $\mathbf{\square}$ & $\square$ & $\square$ & $\square$ & $\square$ & 口 & $\square$ & $\square$ & $\square$ & $\square$ & $\square$ & $\square$ & $\square$ & $\mathbf{X}$ \\
\hline Vla. & $\square$ & $\square$ & $\square$ & $\square$ & 口 & $\square$ & $\square$ & $\square$ & $\square$ & $\square$ & 口 & $\square$ & 口 & $\square$ & $\mathbf{\square}$ & $\square$ & $\square$ & $\square$ & $\square$ \\
\hline Bass & $\boldsymbol{\square}$ & 口 & 口 & 口 & $\mathbf{\square}$ & $\square$ & 口 & $\square$ & 口 & 口 & 口 & $\square$ & 口 & 口 & $\boldsymbol{\square}$ & $\square$ & 口 & 口 & 口 \\
\hline
\end{tabular}

The same is true for the instrumentation of orchestra-tutti (Fig. 10). In some symphonies there are no tone-colour repetitions (KV 162 and 201) while in certain others (KV 199 and KV 202), the opposite is true.

Up until this point, six concert symphonies and six opera overtures by J. Mysliveček with six concert symphonies by W. A. Mozart have been analysed and compared. Due to the limited size of this article, it would be possible to compare these 18 works in only exemplary fashion. In order to deduce more concrete results from this statistical method, there would be a need to consider all the above-mentioned aspects of tone-colour analysis for all 18 works from an over-arching perspective. Only in this way will it be possible to observe long-term tendencies and templates, which would otherwise remain hidden. Diagr. 1 to 11 aim at recognizing such templates and illustrating them. Every diagram represents one instrumentation aspect:

- Diagr. 1: How often the instrumentation of the melody line changes (total number of tone-colour constellations / number of bars)

- Diagr. 2: Tone-colour differentiation (total number of tone-colour constellations / how many of them are different) 
- Diagr. 3: Tone-colour space A (total number of tone-colour constellations / number of melodies in one octave)

- Diagr. 4: Tone-colour space B (total number of tone-colour constellations / number of melodies in two octaves)

- Diagr. 5: Melodies in thirds and sixths versus melodies in unison and/or in one or two octaves (total number of melodies in thirds and sixths / total number of tone-colour constellations)

- Diagr. 6: How often only the first violins perform a melody (total number of melodies only with first violins / total number of tone-colour constellations)

- Diagr 7: How often only the violins (first and seconds) perform a melody (total number of melodies only with violins / total number of tone-colour constellations)

- Diagr. 8: How often the lower strings participate (total number of melodies with lower strings in them / total number of tone-colour constellations)

- Diagr. 9: How often the brass instruments participate (total number of melodies with brass instruments in them / total number of tone-colour constellations)

- Diagr. 10: How often the oboes participate (total number of melodies with oboes in them / total number of tone-colour constellations)

- Diagr. 11: Density (number of instruments performing a melody and how often)

On the left side of each diagram are the six concert symphonies by J. Mysliveček, in the middle his six opera overtures and on the right the six concert symphonies of W. A. Mozart.

Diagram 1 shows how constant the mean values (frequency of changes in instrumentation) remain in J. Mysliveček's concert symphonies compared to his opera overtures. Although there is no exact date of when Symphonies nos. 42-47 were composed, it can be assumed that J. Mysliveček himself considered these works as one unity. The same can be observed in diagram 2 where we see the tone-colour differentiation. Although the opera overtures by J. Mysliveček and the six symphonies by W. A. Mozart do not show such a unity of mean values, the opposite is true for J. Mysliveček's six concert symphonies. As already mentioned here, a higher mean value in a symphony does not automatically mean that the work is of higher artistic quality compared to the others. 


\section{Diagram 1}

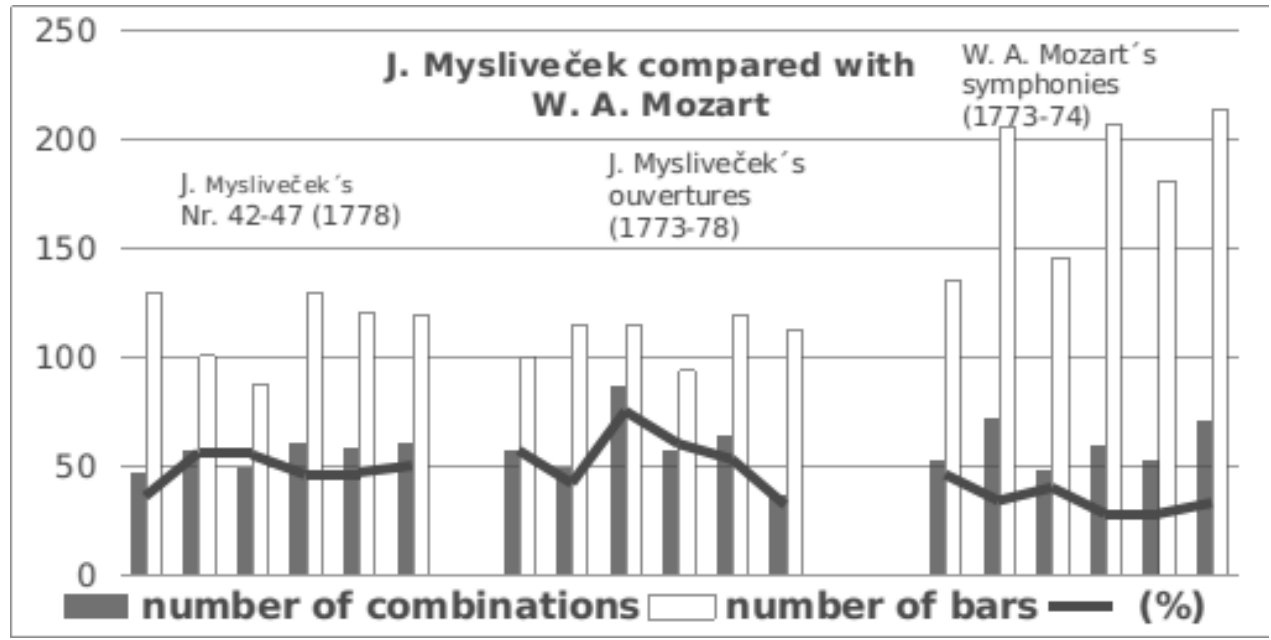

\section{Diagram 2}

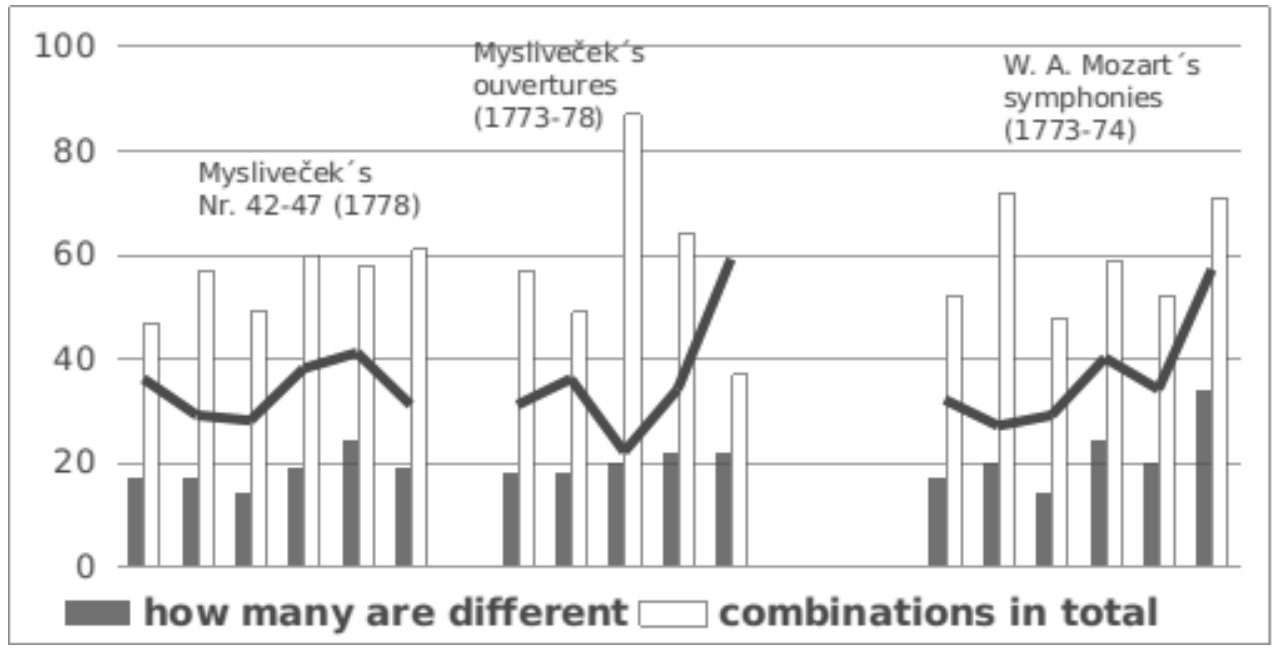

Diagrams 3 and 4 show that, from a statistical point of view, there are more melodies in two octaves in Mozart's symphonies and especially in Mysliveček's opera overtures than in his concert symphonies. The tone-colour space of these orchestral works is wider than the one of Mysliveček's symphonies. His overtures sound, from an over-arching perspective, more brilliant than his concert symphonies. 


\section{Diagram 3}

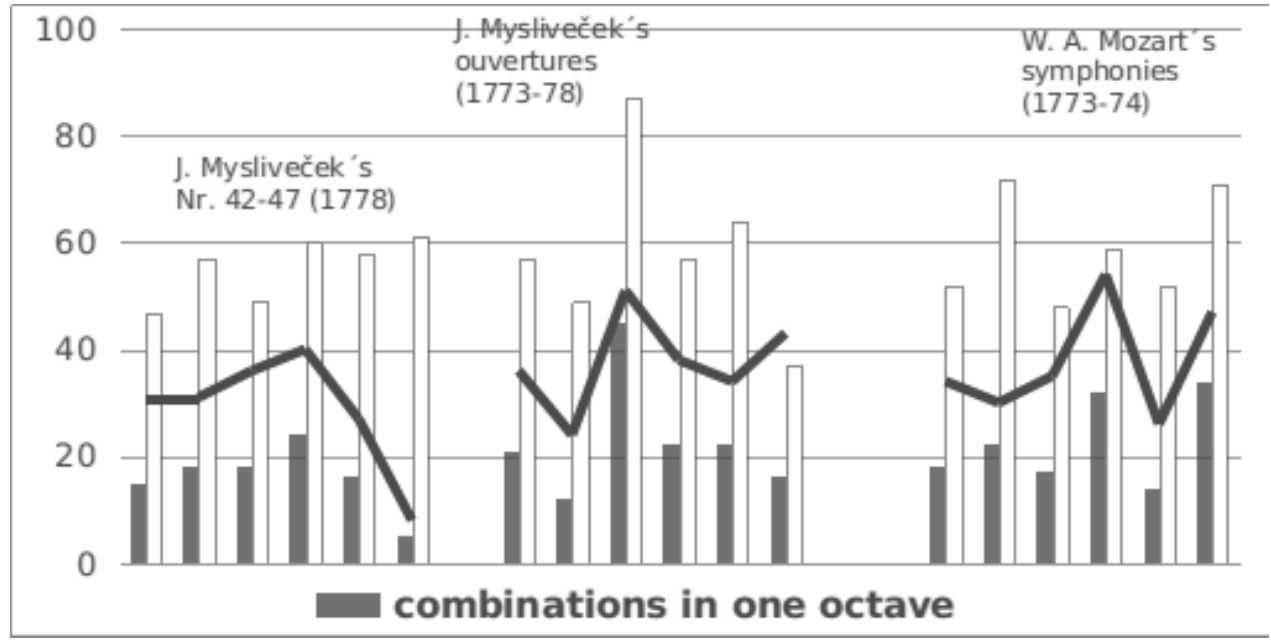

\section{Diagram 4}

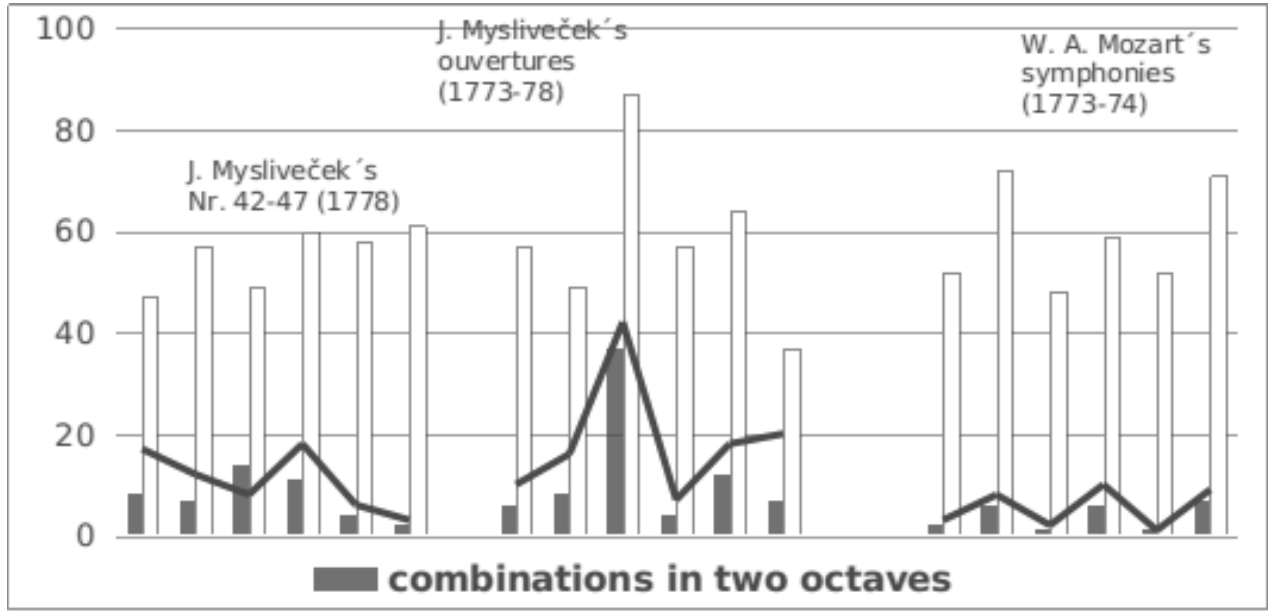

A similarity between almost all 18 symphonic works considered is demonstrated in diagram 5 . In the vast majority of the symphonies, both composers prefer melodies in unison and in one or two octaves, than melodies in thirds, sixths or tenths. Some of Mozart's symphonies are an exception to this rule. 


\section{Diagram 6}

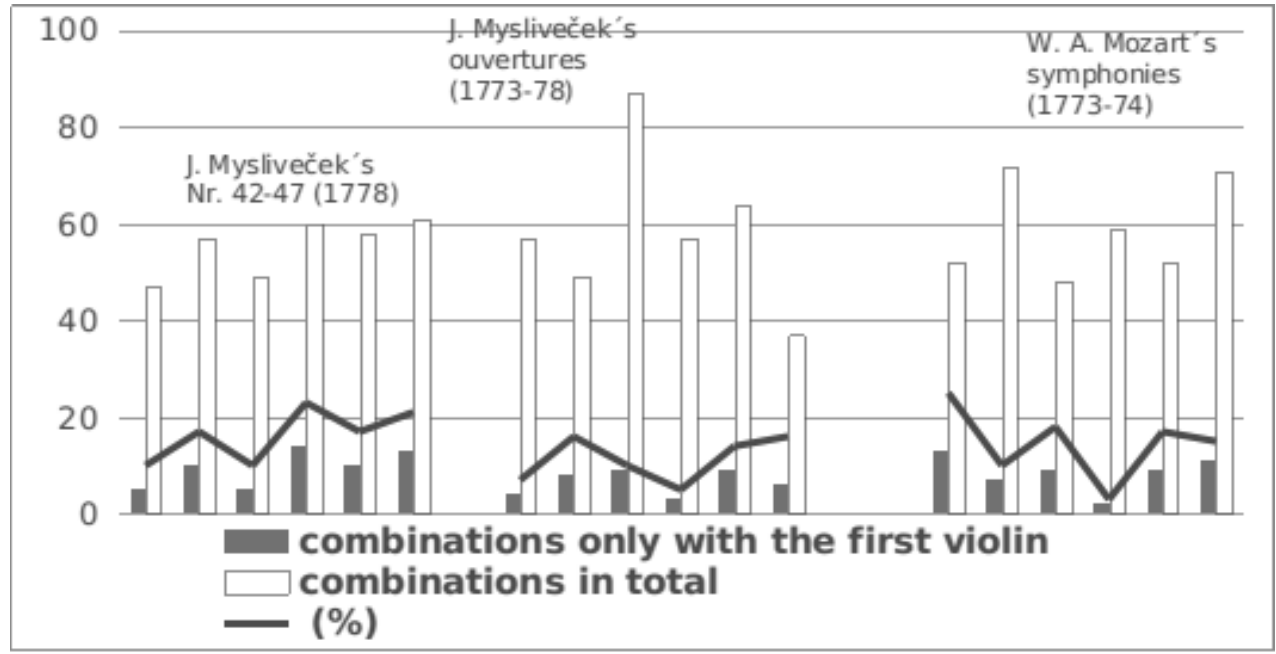

\section{Diagram 7}

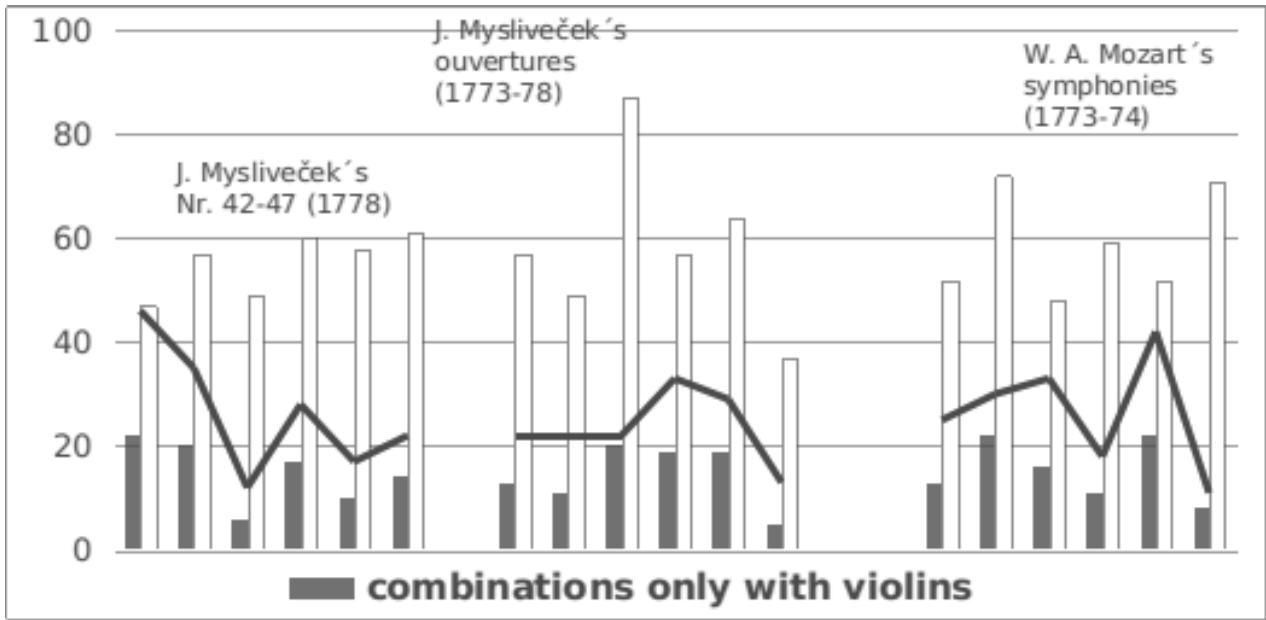

Over the course of the 1770s, the dominance of the violins in the performance of a melody gradually demises. Diagrams 6 and 7 confirm this tendency. Almost every symphony of this comparative study has less than $20 \%$ of constellations with only the first violins and less than $30 \%$ with both first and second violins. There are obviously symphonies by both composers which deviate from this template, but they are the minority. 


\section{Diagram 8}

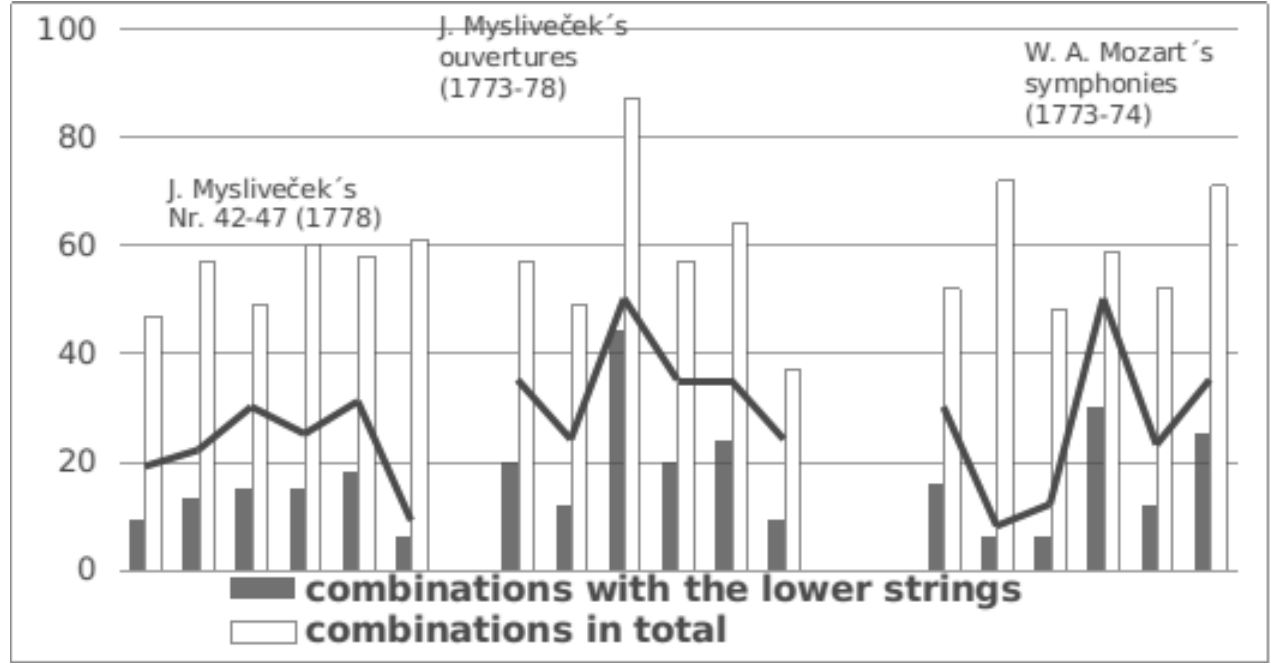

\section{Diagram 9}

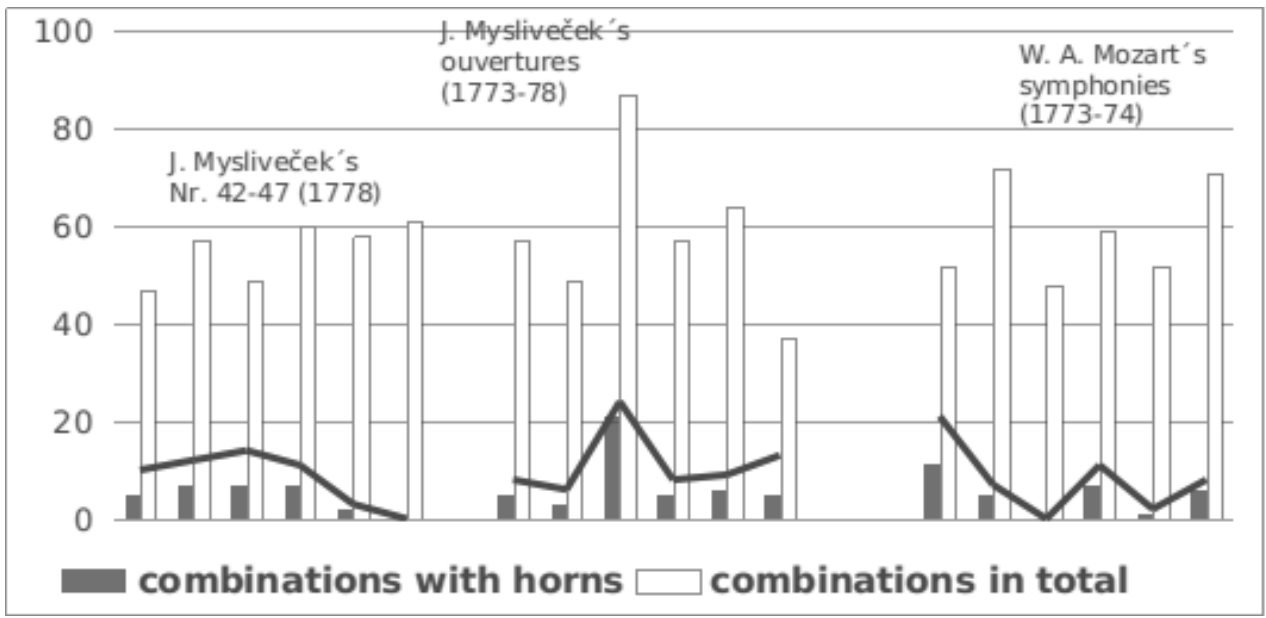

In the opera overtures by J. Mysliveček, one hears melodies with horns and low strings. These works have a more brilliant sound than the concert symphonies (Diagr. 3 and 4) and they also include melodies with instruments which are not usually used for the performance of a melody (Diagr. 8 and 9). 
The tone-colour of the oboes dominates almost every symphony (Diagr. 10), except in some of Mozart's symphonies. In many diagrams (Diagr. 5, 7, 8 and 10) there are symphonies by Mozart which partly deviate from this template. In many aspects, J. Mysliveček's symphonies are more homogeneous and similar to each other than the six concert symphonies by Mozart.

Diagr. 11 is designed somewhat differently than Diagr. 1 to 10 . The number of participating instruments is represented by a surface area, each of which has a different colour. There are almost no melodies with three instruments in J. Mysliveček's works, except in some opera overtures. There is a complete different image in the works by Mozart: his symphonies are characterized by a balance with respect to the tone-colour density of the melody line. In his symphonies one hears melodies with one, two, four or more instruments as well as with three.

\section{Diagram 10}

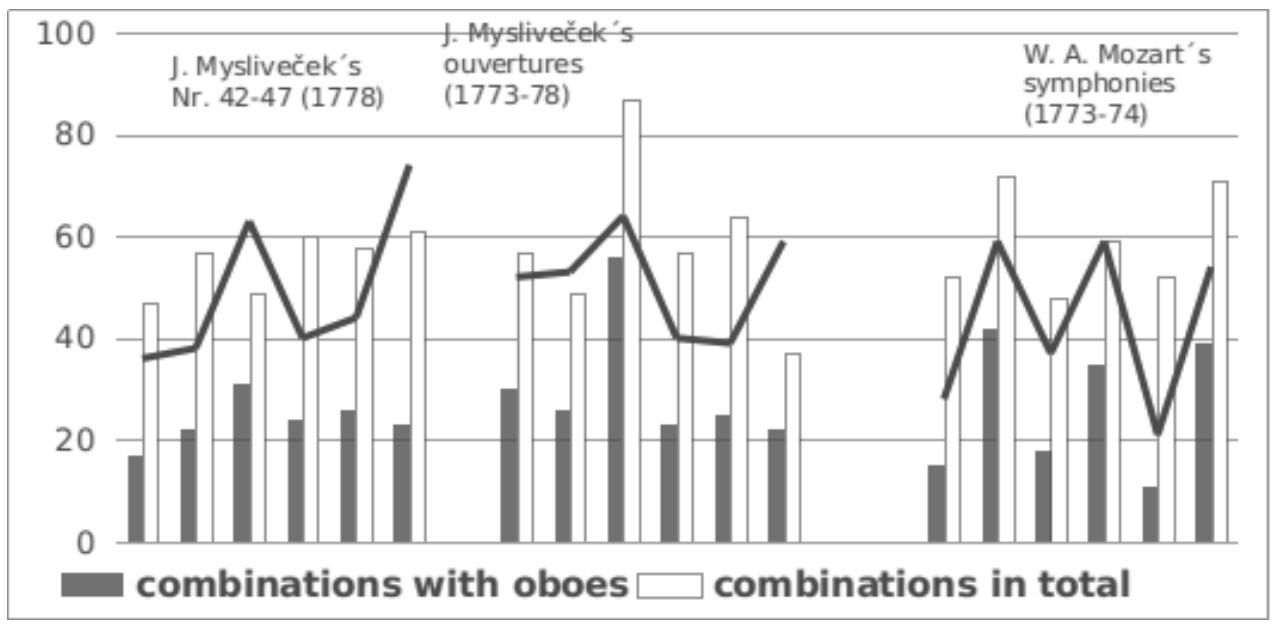




\section{Diagram 11}

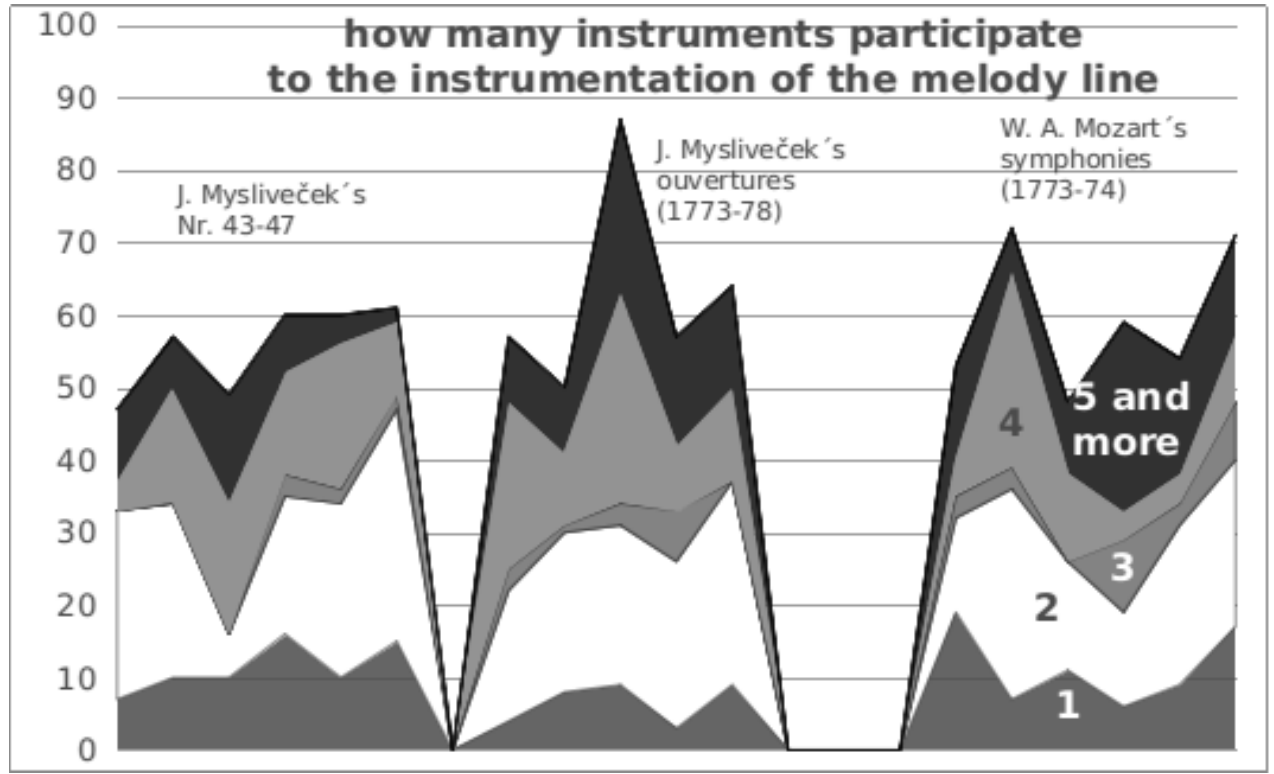

Diagr. 1 to 11 indicate how problematic it is to try and speak of an instrumentation style. It is quite usual that during an instrumentation class, the students are encouraged to instrument one piano sonata of W. A. Mozart with "the typical" Mozart instrumentation. Diagr. 1 to 11 reveal, however, that even within a small time window, Mozart instruments his symphonies quite differently. J. Mysliveček not only instruments his symphonies in another manner than W. A. Mozart, but actually changes his preferences when composing a concert symphony or an opera overture.

Despite the different instrumentation template the two composers use, there are similarities between them in terms of how they design the melody. The melody tone-colours, the tone-colour space and the density all change constantly during a symphonic part. Through different combinations, melodies in different intervals are doubled or played in octaves. All orchestra instruments participate in the performance of melodies and at least on third of each part has no tone-colour repetitions.

These tone-colour characteristics are to be expected in the works of W. A. Mozart. It is surprising, however, that they also exist and in quite a high number in the symphonic works of J. Mysliveček. His symphonic oeuvre has unfortunately received little attention from musicological research and has seldom been used for comparative studies. This paper hopes to partly fill this hole. 


\title{
On the Instrumentation of the Melody Line of Joseph Mysliveček's \\ Symphonies Nos. 42-47
}

\begin{abstract}
The aim of this paper is to look at the design of the melody line in J. Mysliveček's Symphonies nos. 42-47 (ED. 10: D21, F8, Bb8, Eb6, G10 and C11) from a music-analytical perspective. The following aspects are presented in details: instrumentation of the bass line, octave doublings of the melody line within a movement, as well as the participation of the low strings and the brass section in the performance of the melody. These symphonies will then be compared with opera symphonies from the same period which also have the same instrumentation, in order to find differences and similarities between them. Furthermore, J. Mysliveček's symphonies are compared to symphonies by W. A. Mozart of the same period (1772-1774) with the same instrumentation to determine relationships on the one hand, and to stress special features of the symphonic works of J. Mysliveček on the other hand.
\end{abstract}

\section{K instrumentaci melodické linie v Symfoniích č. 42-47 Josefa Myslivečka}

\begin{abstract}
Abstrakt
Příspěvek se zabývá hudební analýzou melodických linií v Symfoniích č. 42-47 (ED. 10: D21, F8, Bb8, Eb6, G10 and C11) J. Myslivečka. Detailně jsou zkoumány následující aspekty: instrumentace basových linií, oktávová zdvojení melodie v rámci hudební věty, podíl smyčcových a žestových nástrojů na provedení melodie. Symfonie jsou srovnávány s Myslivečkovou orchestrální operní hudbou ze stejného období, která využívá identickou instrumentaci, stejně tak s podobně instrumentovanými symfoniemi W. A Mozarta z období 1772-1774. Cílem komparace je určit společné jmenovatele děl obou tvůrců, dále definovat specifický kompoziční rukopis J. Myslivečka.
\end{abstract}

\section{Keywords}

Instrumentation; J. Mysliveček; W. A. Mozart; symphonies; tone-colour analysis.

\section{Klíčová slova}

Instrumentace; J. Mysliveček; W. A. Mozart; symfonie; analýza témbru. 